\title{
Comparison of Self Efficacy on Cognitive Apprenticeship and On The Job Training
}

\author{
Setiyo \\ Teknologi Pendidikan \\ Universitas Negeri Surabaya \\ Surabaya, Indonesia \\ Setiyo@unesa.ac.id
}

\author{
Yatim Riyanto \\ Teknologi Pendidikan \\ Universitas Negeri Surabaya \\ Surabaya, Indonesia \\ Setiyo@unesa.ac.id
}

\author{
Lutfiyah Nurlaila \\ Teknologi Pendidikan \\ Universitas Negeri Surabaya \\ Surabaya, Indonesia \\ Setiyo@unesa.ac.id
}

\begin{abstract}
Vocational education prepares the workforce, so that in the process required learning that closer to the world of work. Internship there are two methods, namely cognitive apprenticeship and on-the-job training (OJT). The cognitive apprenticeship method is designed to bring the tacit process indirectly openly, where learners can observe, enact, and practice with the help of learners and other learners. OJT is a work instruction that occurs in the work environment and during work. Self-efficacy is a self-assessment belief with regard to one's competence to succeed in his tasks. In both methods, it is necessary to examine the effect on the self-efficacy of the apprentices. Because the factor of self-efficacy can affect success in the work. CA emphasizes problem-solving and task assignments and focuses on guiding cognitive and metacognitive learning, not on the physical, skills and processes. OJT is a work instruction that occurs in the work environment and during work, so in its implementation there tends to be no active participation from the participants. The results show that $\mathrm{CA}$ greatly affects the self-efficacy of interns rather than OJT. In cognitive apprenticeship placements, participants are given the freedom to solve the problems gained so as to have an impact on increased confidence. While on the OJT, the participants only followed instructions from the instructors in the field.
\end{abstract}

Keywords-cognitive apprenticeship; on-the-job training; selfefficacy; aviation

\section{INTRODUCTION}

The reality of the working world has changed rapidly. This change is related to knowledge and technology innovation, so it is necessary to prepare workers with knowledge and soft skills. Trends in vocational education in developed countries followed by developing countries today include (1) upper middle massification, (2) creating broader vocational education for a group of jobs in a particular sector, (3) higher levels of diversification in terms of content, which indicated on the use of the labor market, provider institutions, and mode of delivery [1]. Furthermore, Matveeva and Lapp proposed a more flexible apprenticeship reform and increased attractiveness in the eyes of young people and encouraged employers' involvement.

Internships that have been done so far have not been aligned with the expectation of vocational education goals in accordance with the demands of the world of work, as recommended by UNESCO 2001. Internship activities are expected to develop problem-solving skills, soft skills, and ability to think. The apprenticeship should be able to align the knowledge and skills that have been acquired in the academy with the world of work. Internships must be designated into learning environments in a social context with concrete tasks guided by experts as partners, and strived for action on cognitive competence and skills appropriate to real problems [2]. Vocational education should provide a productive career base that provides a background in knowledge, skills, and attitudes, to continue education at every point in an individual's working life [3]. Vocational education raises the core capabilities of problem-solving, interpersonal skills and communication [4]. This suggests that the development of problem-solving skills is central to vocational education, as it relates to the world of work.

Self-development in vocational education is the main thing. It deals with the ability of interpersonal and soft skill learners in the world of work. Self-efficacy is a motivational construct that has been shown to influence the choice of individual activity, goal level, persistence and performance in various contexts [5]. [6] Demonstrates the results of selfefficacy studies that demonstrate consistent findings, as has been shown to be related to performance, facing tasks related to difficult careers, learning, and achievement and ability to adapt to new technologies. Self-efficacy is associated with the achievement of academic goals [7]. Several studies have found self-efficacy to be a better predictor of subsequent 
performance of past behavior (Bandura, 1977a, Bandura, 1982 Bandura \& Adams 1977 Bandura, Adams, \& Beyer 1977 Bandura, Adams, Hardy, \& How-ells, 1980; Chambliss \& Murray, 1979 in Gist, 1987) [7]. Self-efficacy has a strong influence on the achievement of academic goals and performance of a person.

\section{METHOD}

This study aims to compare between two groups using cognitive apprenticeship with OJT on self-efficacy by using paired sample test. The research design used posttest-only control group. Research subjects are apprenticeship of 141 cadets of Aviation Polytechnic of Surabaya. They performed an internship with two models, CA (70) and OJT (71) for three months.

\section{RESULTS AND DISCUSSION}

The result of data analysis can be concluded that there are differences in self-efficacy after following the internship with cognitive apprenticeship and OJT model. Participants who follow internship with CA method have higher self-efficacy compared to OJT. Teaching methods that emphasize in internships provide students the opportunity to observe, engage in, and create or find expert strategies in context. OJT is one of the internship methods commonly used in an organization because it is flexible and relevant to what is done [8]. OJT is a work instruction that occurs in the work environment and during work [9] OJT only work instructions that occur in the work environment and during work [9].

[9] Explained that in the implementation of OJT tends to be haphazard and unplanned. The workers following the new OJT observe, practice, study by trial and error and sometimes receive direct instruction (if experienced workers do not feel threatened by competition). [8] Agrees with Rothwell, OJT has some issues, those who do the training may have no experience in training, no time to do so, or no desire to participate in it and that OJT can interfere with routine work, bad habits or misinformation from superiors or managers can be transferred to participants.

Cognitive apprenticeship makes participants active in learning by working along the side of the structure during the production of artifacts, such as arguments and explanations [10]. [11] Explains that on the idea that all significant human activity lies deeply in context and the real world that complex cognitive skills are therefore ultimately studying in highcontext, inherently motivating situations in which the skills themselves are organically bound to the activity being studied and expert user communities.

Cognitive apprenticeship emphasizes problem-solving and task tasks, and focuses on guiding cognitive and metacognitive learning, not on physical, skill and process [12]. With cognitive apprenticeship, learners will be faced with real, situational, and meaningful practices [2] . [2] Explains that cognitive apprenticeship emphasizes knowledge that is inseparable from the context and activities in which it develops. The use of cognitive apprenticeship brings the learner closer to contextual learning. Contextual learning by
Imel (2000) in Magro (2009) emphasizes problem-solving, acknowledging that teaching and learning need to take place in several contexts, helping students learn how to monitor their learning so that they can become independent learners; linking in the context of the diverse lives of students, encouraging students to learn from each other, and hiring authentic judgments.

The key to vocational education according is to facilitate the construct of knowledge through experimental, contextual, and social methods in the real-world environment. Both methods, OJT and cognitive apprenticeship, is one of the closer learners with the real world associated with the work that will be done. Vocational education requires the ability to think and solve problems that have social attitudes. Implementation of OJT only displays the process of transferring knowledge, and in implementation, there are often constraints. Cognitive apprenticeship emphasizes the thinking process by focusing on metacognitive and problem-solving. Cognitive apprenticeship methods are able to develop problem-solving skills, soft skills, and thinking skills as UNESCO 2001 recommends. Cognitive Apprenticeship focuses on the four dimensions of each learning environment: content, methods, systematics, and sociology. This method develops metacognitive and problem-solving abilities. So in the internship activities, the cadets will be able to learn from the experts in their field and develop self-ability, in this case is self-efficacy.

\section{CONCLUSIONS}

Vocational education is an education that prepares participants able to work in accordance with the competence. Thus, it is very necessary workplace training directly in the workplace. Cognitive Apprenticeship has proven capable of improving the self-efficacy of apprentices. The apprenticeship process in Cognitive Apprenticeship is able to involve participants in problem-solving and decision-making processes, thereby increasing self-esteem. OJT, participants tend to wait for supervisory guidance in problem-solving which resulted in less courageous participants in decision making.

\section{REFERENCES}

[1] N. Matveeva and J. Lapp, "Overview: Participation in Formal Programmes of Learning and Skills Development," in International Handbook of Education for the Changing World of Work, ed: Springer, 2009, pp. 2025-2037.

[2] M. Gessler, "Situated learning and cognitive apprenticeship," in International handbook of education for the changing world of work, ed: Springer, 2009, pp. 1611-1625.

[3] I. UNESCO, "Revised recommendation concerning technical and vocational educational (2001)," ed: Paris UNESCO, 2002.

[4] H. Connell, N. Lowe, M. Skilbeck, and K. Tait, The vocational quest: New directions in education and training: Routledge, 2002.

[5] H. Zhao, S. E. Seibert, and G. E. Hills, "The mediating role of selfefficacy in the development of entrepreneurial intentions," Journal of applied psychology, vol. 90, p. 1265, 2005.

[6] A. Maritz and C. Brown, "Enhancing entrepreneurial self-efficacy through vocational entrepreneurship education programmes," 
Journal of Vocational Education \& Training, vol. 65, pp. 543-559, 2013.

[7] M. E. Gist, "Self-efficacy: Implications for organizational behavior and human resource management," Academy of management review, vol. 12, pp. 472-485, 1987.

[8] R. L. Mathis and J. H. Jackson, Human resource management: Essential perspectives: Cengage Learning, 2011.

[9] W. J. Rothwell and H. C. Kazanas, Improving on-the-job training: How to establish and operate a comprehensive OJT program: John Wiley \& Sons, 2004.
W. A. Sandoval and K. A. Millwood, "The quality of students' use of evidence in written scientific explanations," Cognition and instruction, vol. 23, pp. 23-55, 2005.

[11] D. Atkinson, "A critical approach to critical thinking in TESOL," TESOL quarterly, vol. 31, pp. 71-94, 1997.

[12] A. Collins, "Cognitive Apprenticeship: Teaching the Craft of Reading, Writing, and Mathematics. Technical Report No. 403," 1987. 